an oddness of its own. However, being on the outside, or not belonging, carries with it a certain freedom. Mary Lou Pardue wrote that she felt freer to take risks be cause "I never had any expectation that I was going to be on a faculty; therefore I did what I wanted to do... I took more risks than I might have taken had I thought I was going to be a success. I did science that I thought was interesting." Joan Steitz wrote that what "I wouldn't have done if I weren't a woman was choose a very risky research project." Being unconventional, not following scientific fashion and being out of the mainstream early in their careers did not faze Wasserman's correspondents. Besides, as Nancy Kopell wrote, "Eventually the mainstream caught up with me." Or, more directly, "To hell with the critics" (Mildred Cohn).

The book A Door in the Dream would make a terrific gift for a young woman in science_or for her parents or teachers. But, selfishly, I suggest it equally enthusiastically for those of us, women and men, already immersed in this world, for the pleasure of learning about the creativity, tenacity and 'true grit' of some of our colleagues we most admire.

\section{Driving Mr. Albert: A trip across America with Einstein's brain}

\author{
by Michael Paterniti \\ The Dial Press, 211pp, $\$ 18.95$ \\ ISBN : 0385333005
}

\section{ReVIeWEd by Steve HorWitz} Production Editor, Nature M edicine

The real story here takes place on April $18^{\text {th }}, 1955$ in the dank, dark morgue of Princeton Hospital. The recently deceased Albert Einstein, contemplating calculations until his final breath, lays still on the metal gurney. Dr. Thomas Harvey, then a 42 year-old chief of pathology at the hospital, enters the morgue, takes out his scalpel and goes to work on the corpse. And during the course of this routine autopsy on an anything but routine cadaver, Dr. Harvey makes a decision; one that will cast a shadow on his entire existence up to this very day. He removes Einstein's brain. And then hetakes it home with him, storing it in a Tupperware container in his closet. Some branded him a hero, a man willing to risk his reputation in order to keep the brain from becoming an exhibit, something yokels gawk at when the county fair is in town. Others, especially the surviving members of the Einstein family, were not so kind.

And this is where Paterniti's cross country odyssey comes in. The idea started as an article for Harper's W eekly, an idea good enough to win him the 1998 National Magazine Award. And that article became this book. It really is a fascinating premise. A first-hand glimpse into the Yale-educated mind of one of this century's most notorious brain-nappers. And a showdown with thesurviving family that wants it back. For it was the author's idea to set up the meeting between Einstein's granddaughter, a research scientist at The University of California at Berkley, and the aforementioned grave robber/pariah.

Neither participant was pleased with the idea of meeting the other, but Paterniti kept on pushing for the meeting, and finally, miraculously, it was agreed upon. A date and place were settled on; all that remained for Paterniti was the small matter of driving both Harvey and the brain across the endless interstates connecting one coast of America with the other. Against this constantly changing landscape, Paterniti ruminates. He tells us about Einstein's life, wondering what the great intellect would think if he were sitting shotgun for the drive. He worries about his own life; there's a rocky unresolved relationship waiting back home for him in Maine. Hetalks with Harvey, trying to mine as many yarns and tidbits as he can from

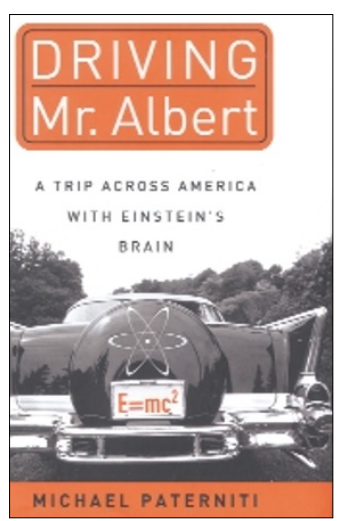
the doctor's brain, especially regarding the more famous brain in the trunk. And the car drives on, building up for the climactic meeting. The custody battle for one of the world's most famous organs. An ethical debate raging between humane sentiment and the unquenchable thirst for knowledge.

But in the end, nothing happens. Harvey offers her some of the brain but Einstein's granddaughter decides she doesn't want it. And everyone goes home. "It all seems so anticlimactic, but so appropriate," Paterniti says of the meeting. At least he got a book out of theencounter. For the reader, however, there is nothing appropriate about it. Anticlimactic endings are like taking your dog for a walk only to watch him urinate on your rug when you come back home. Not that the walk itself wasn't enjoyable, just that the end result leaves a lot to be desired.

Similarly, Paterniti's romp through the wilderness is at times both entertaining and enlightening. He does a commendable job presenting Harvey as an interesting individual, even though it's clear from the doctor's dialogue he's anything but. The historical perspective of Einstein's life is also interesting, though it occasionally feels like a crutch Paterniti leans on when the endless hours on the road leave him scrounging for pages to fill. A visit to William Burrough's home in Lawrence, Kansas is quite entertaining. An associate of Harvey's while in Kansas, one certainly wonders what a meticulous pathologist and a belligerent Morphine-addicted author could possibly talk about, except for the former explaining to the latter all the damage being done to his cerebellum.

But in the end, all those nice moments along the way fail to justify the journey. Tangents are fine, but part of their charm comes from knowing that they are deviations from the route. In Driving $\mathrm{Mr}$. Albert, those tangents function as the redeemer of a failed plot and not the segue between arcs of the story. Now I'm not suggesting the author should have taken a few "creative liberties" and added a few car chases or disproportional waitresses in all-night truck stops with acoustic guitars and Grammy aspirations. But how can you be in a car with the man who has hoarded Einstein's brain in a Tupperware container for over forty years and not ask him why he took it? Or why he still has it and won't give it up to a Hospital or University for other studies? The common thread running through all scientists is a simple question. Why? And it's the same thread that binds all readers. By the end of this book, you'll know a great deal about Harvey's failed relationships, the unmistakable smell of half a dozen cheap highways motels, that Joseph Stalin founded the Moscow Brain Institute in 1926 to study Lenin's recently removed noggin. And yet you still don't know why he took the brain in the first place. It doesn't take Albert Einstein to notice how unbalanced that equation really is. 